\title{
Youth development in rural library: ICT gratification as mediating effect
}

\author{
Samsul Farid Samsuddin ${ }^{1 *}$, Siti Zobidah Omar $^{2,3}$ and \\ Hayrol Azril Mohamed Shaffril ${ }^{3}$ \\ ${ }^{1}$ Research and Information Services Division, Sultan Abdul Samad Library, \\ Universiti Putra Malaysia, 43400 Serdang, Selangor Darul Ehsan, MALAYSIA \\ ${ }^{2}$ Faculty of Modern Language and Communication, \\ Universiti Putra Malaysia, 43400 Serdang, Selangor Darul Ehsan, MALAYSIA \\ ${ }^{3}$ Institute for Social Science Studies \\ Universiti Putra Malaysia, 43400 Serdang, Selangor Darul Ehsan, MALAYSIA \\ e-mail: *sfarid@upm.edu.my (corresponding author); \\ zobidah@upm.edu.my; hayrol@upm.edu.my
}

\begin{abstract}
This study investigates the relationship between ICT facilities and behavioural factors with positive youth development among rural youth in Malaysia, considering gratification of ICT usage in rural library as the mediating effect. The youth in rural areas are inclined to involve in negative affairs due to non- established beneficial activities. Therefore, the government has taken initiatives to equip rural libraries with ICT facilities and services to support social and academic activities amongst youth. A total of 400 respondents comprising rural library users in Peninsular Malaysia aged between 15 to 40 years were surveyed through multi-stage cluster simple random sampling. A survey method was employed and the analysis was conducted using Structural Equation Modelling (SEM). The results revealed that gratification of ICT usage among youths in rural library do not significantly mediates the relationship between ICT and specific behavioural factors in positive youth development. The finding indicates that respondents were not entirely depending on ICT facilities provided in the rural libraries in their undertakings. This study highlights several implications and recommendations for policy makers and practitioners towards improving ICT provisions in rural libraries in Malaysia.
\end{abstract}

Keywords: ICT usage; ICT gratification; Rural libraries; Rural youth; Positive youth development

\section{INTRODUCTION}

Several government initiatives have been implemented to foster Malaysia towards becoming one of the developed nation in the world. Rural areas are not neglected in national efforts on planning and development of such initiatives. Equal developments between urban and rural areas are indispensable in national development programme. Rural libraries have been part of government initiatives in promoting community development through increasing the quality of social and economy of rural communities in Malaysia. Albeit the initiatives, the aim is to provide the rural communities with learning centres, information services and readily information together with comprehensive and complete recreational facilities in order to improve literacy rate (Muhammad 2004). Furthermore, Malaysian government intends to reduce the gap between rural and urban communities particularly in information acquisition. Elaborating the importance of rural library to the users and 
community development, it is said that rural libraries should continuously provide access to the information and knowledge (Goulding 2008). Report by the National Library of Malaysia (NLM) indicated that there were about RM30 million (USD 10 million) of operating budget spent annually for 475 rural libraries in strengthening the library ICT infrastructure and facilities. This shows that the government is really committed in sustaining the quality of life of the rural areas (NLM 2015). As of June 2015, the number of rural libraries under the jurisdiction of NLM has rapidly increased to a total of 501. There are 5,345,674 copies of accumulative collection in the rural libraries and a total of 596,734 of ICT usage have been recorded (NLM 2015) as shown in Table 1.

Table 1: Rural Library Parameters (NLM 2015)

\begin{tabular}{lr}
\hline Parameters & $\mathbf{2 0 1 5}$ \\
\hline No. of library & 501 \\
Membership cumulative & 447,893 \\
No. of visitors & $2,268,978$ \\
No. of users & $1,851,025$ \\
No. of borrowing collection & $1,330,607$ \\
No. of ICT usage & 596,734 \\
Collection cumulative & $5,345,674$ \\
No. of organize activity & 35,150 \\
No. of public participant & 616,058 \\
\hline
\end{tabular}

Rural libraries which are equipped with ICT facilities and services (inclusive of Internet) act as agents in community development by creating activities that positively impact the economy and social life of rural communities (Bashir et al. 2011; Samah et al. 2011). The use of ICT could give impact on the growth and advancement of a society such as in economy, education, communication and mobility which could promote opportunities for positive development (Thioune 2003). As such, rural libraries have the same effect of telecentres, and to what extent the rural communities, especially the youth have fully utilized the facilities and services provided needs investigation.

However, Elbert and Alston (2005) reported that youth in rural areas often have less accessibility to technology assets than their counterpart in the urban, therefore this affects them in educational growth, job opportunities and skill development. As a result, delinquent behaviours among rural youth were on the rise (Caldwell and Smith 2006). Positive Youth Development (PYD) has provided a broad and balanced view of youth development by providing a paradigm shift that moves away the prevailing focus of maladaptive behaviour amongst adolescence (Cowen 2000; Damon 2004; Brown 2005). PYD that was introduced by Lerner et al. (2005) emphasizes on positive vibes among the youth. According to Malaysian Youth Council, youth are those in age ranged between 15 to 40 years old. In line with Act 668 Youth Societies and Youth Development Act (2007), they are the key players in development of a country (KBS 2007). In accordance to that, for social and economy growth, appropriate infrastructures for youth could be a contributing factor for rural youth development. In Malaysian context, most of youth feel that they can make a little change at the community level, while only few of them feel the opposites. This is evident in a survey conducted by The Asia Foundation on 2012 which has reported the sense of empowerment amongst rural youth was particularly strong $(48 \%)$ compared to urban youth $(37 \%)$ (The Asia Foundation 2012).

This paper reports on the role of ICT that could facilitate the development of youth towards more positive lifestyle. This study was conducted to ascertain the ICT usage amongst youth in rural libraries towards their PYD. PYD is a strength-based and resource-focused approach, 
which emphasizes explicit definitions of positive outcomes, and embraces an optimistic view of youth (Roth and Brooks-Gunn 2003; Damon 2004). PYD is a concept about involvement of young people in community services, systems and activities. The main goal of PYD approach is to help young people in acquiring knowledge and developing their skills towards healthy, happy, responsible, and productive adults they need to become (Bean, Winzeler and Baber 2005). Limited studies were reported on PYD and its relation to the gratification of ICT usage. Therefore, the roles of ICT in shaping the development of youth in rural areas particularly through the rural advancement initiative provided by rural libraries is interesting to be investigated. Apart from the general Internet usage survey as reported by the Malaysian Communication and Multimedia Commission (MCMC 2016), there has been lack of empirical evidence in terms of utilization of ICT services in rural libraries in Malaysia as reported in previous literature (Norshila, Masitah and Wan Nor Haliza 2011; Samah et al. 2011; Omar et al. 2012; Mazuki et al.2014; Omar et al. 2014; Samsuddin et al. 2015; Zaremohzzabieh et al. 2015; Omar et al. 2016).

The objective of this paper is to investigate the associations between ICT facilities factors as well as behavioural factors, and PYD through the mediating effect of gratification of ICT usage among youth in rural libraries of Malaysia. There are $5 C^{\prime} s$ which were initially introduced (competence, connection, character, confidence, and caring) but an additional element which is 'contribution' was suggested later by Bers (2006) that made up a final of six ' $C$ 's elements. It is of interest to determine the significance of gratification of ICT usage towards PYD based on of 6Cs' dimensions (competence, connection, character, confidence, caring and contribution). This study also attempted to discover whether ICT usage can increase the 6Cs'dimensions of PYD among rural youth and reflect into their actions to avoid negative activities such as drug abuse, alcohol consumption and teenage pregnancy as suggested by Lerner (2004). The following research questions were put forward to conduct the investigation:

a) What is the relationship between ICT factors and behavioural factors on gratification of ICT usage?

b) What is the relationship between gratifications of ICT usage on PYD?

c) What is the relationship between ICT factors and behavioural factors on $6 C^{\prime} s$ dimension of PYD?

d) What is the relationship between ICT factors and behavioural factors on $6 C^{\prime} \mathrm{s}$ dimension of PYD mediated by gratification of ICT usage?

\section{RESEARCH FRAMEWORK}

This research was designed based on several ICT usage theories/models toward rural youth development. Theory of Planned Behaviour (TPB) and Extended Technology Acceptance Model (ETAM) were used as guidelines in measuring factors of the ICT usage in rural library services. TPB by Ajzen (1991) is the most suitable model in explaining human behaviour regarding their needs. ETAM is adapted to overcome gaps and strengthen the TPB theory with some of the variables were considered significant in explaining behaviour towards ICT and development. ETAM is a job related study that been used by in previous studies such as in $\mathrm{Hu}, \mathrm{Clark}$ and $\mathrm{Ma}$ (2003) that examined how people accept technologies in their job scope. The approach of using this theory assumes that rural library users' use of ICT services is purposive and they seek information or doing task to satisfy their needs (Katz, Blumler and Gurevitch 1974). In providing practical solutions to rural library administrators, the current study examined ICT use in rural libraries through behavioural measurements, assuming that when someone forms an intention to act, he will be free to act without limitation. 
Behavioural factor is an important factor to be studied because it provide deeper understanding what really need to be seen on individual in strengthening their Internet use. Previous studies have found there is a significant relationship between actual usage and intention behaviour (Davis, Bagozzi and Warshaw 1989; Ajzen 1991; Eagly and Chaiken 1993; Hu, Clark and Ma 2003; Venkatesh et al. 2003).

Although Joorabchi, Hassan and Osman (2013) have conducted a study on Internet use and PYD with gratifications of Internet usage as mediator, their study only used selected dimensions of PYD as dependent variables and several constructs (e.g. purposes, attitudes, Internet skill, problems and patterns of Internet) as independent variables. This study has hypothesized behaviour factor as well as ICT factor as significantly related with overall important outcomes of PYD namely competence, connection, character, confidence, caring and contribution. To date, no study has reported to investigate the direct and indirect effect of behaviour factor and ICT factor towards PYD. This study aimed to delineate direct and indirect relationship between ICT factor as well as specific behaviour factor and PYD by highlighting the mediating role of gratification of ICT usage.

\section{Positive Youth Development (PYD)}

Previous studies on youth focuses on their negative behaviours such as teenage pregnancy, drug misuse, and crimes (Brown 2005; Theokas et al. 2005) rather than its positive counterpart (Moore et al. 2004; Lerner et al. 2005; Klein et al. 2006). PYD has contributed a broad and balanced view of development, by providing a paradigm shift from the prevailing focus on maladaptive outcomes in adolescence (Brown 2005; Damon 2004 and Cowen 2000). Therefore, PYD that was introduced by Lerner et al. (2005) emphasizes on the positive vibes among the youth. According to Lerner et al. (2005), PYD suggests that if people beneficially engage with people and institutions in their social world, they will be in the right path for the positive future in contributing to themselves, their family, community, and civil society. PYD as dependent variable in this study was an outcome of gratification in using ICT at rural libraries among youth in Malaysia. The working definitions of the PYD 6C's in the context of rural libraries were opportunities and contributions, derived along the rural library usage which also able to develop sense of caring for others especially among rural youth. The rural libraries create an approach where policies and programmes are directed at providing supports to rural youth as they build their capacities and strengths to meet their personal and social needs in terms of competencies. Besides that, it does create the same experiences and practices that adults use to do in fulfilling their healthy development in aspects of connections and supports.

\section{Gratifications of ICT Usage}

Gratifications of ICT usage in this study was derived from Uses and Gratification Theory to explore why and how people use media to fulfil their needs and motives (Rubin 1984). A number of studies were reported on the effectiveness of ICT in benefiting socio-economic aspects in various community such as farmers (Hassan et al. 2011), fisherman (Shaffril et al. 2012, Bolong et al. 2013), village leaders (Samah et al. 2011) entrepreneurs (Hassan et al. 2011), rural community (Hassan et al. 2008), school students (Ismail, Ahmad and Affandy 2013) and teachers (Kumar, Rose and D'Silva 2009). Nonetheless, there were lack of study related to ICT usage among rural youth were conducted.

\section{Behavioural Factor}

Behaviour factor is a positive or negative evaluation that youth experienced in various aspects of ICT usage in rural library. It is suggested that behaviour factor has a multidimensional nature in this study to overcome each theory or model gap. In providing 
practical solutions to rural library administrators, the current study examined ICT usage in rural libraries through behavioural measures adapted from TPB such as Attitude, Subjective Norm and Perceived Behaviour Control (Ajzen 1991) and several variables from ETAM which include Perceived Ease of Use and Perceived of Usefulness and Self-efficacy, adapted from $\mathrm{Hu}$, Clark and $\mathrm{Ma}$ (2003).

\section{ICT Factors}

Malaysian Communication and Multimedia Commission (MCMC) (2014) reported that the Internet usage of Malaysian household was from urban area with 82.2 percent and 17.8 percent from the rural. Information seeking through Internet has increased from 48 percent in 2012 to 90 percent in 2016 (MCMC 2016). Workplaces, schools, libraries, cybercafés, and premises with free Wifi, have been identified as places for people who are not subscribed to the Internet connectivity to access the network. Bertot et al. (2009) in their study reported users' alternative Internet access points and applications they accessed. This has shown that the availability of facilities and access are the dimensions for the ICT factors in rural community.

\section{Research Hypotheses}

Based on the above discussions, a research framework (shown in Figure 1) was developed, and the following seven hypotheses were established:

$\mathrm{H1}$ : There is a significant relationship between ICT factors and gratification of ICT usage.

$\mathrm{H} 2$ : There is a significant relationship between behavioural factors and gratification of ICT usage.

H3: There is a significant relationship between gratifications of ICT usage and PYD.

$\mathrm{H} 4$ : There is a significant relationship between ICT factors and $6 C^{\prime}$ 's dimension of PYD.

$\mathrm{H} 5$ : There is a significant relationship between behavioural factors and $6 \mathrm{C}^{\prime} \mathrm{s}$ dimension of PYD.

H6: There is a significant relationship between ICT factors and 6C's dimension of PYD, mediated by gratification of ICT usage.

H7: There is a significant relationship between behavioural factors and $6 C^{\prime}$ 's dimension of PYD, mediated by gratification of ICT usage.

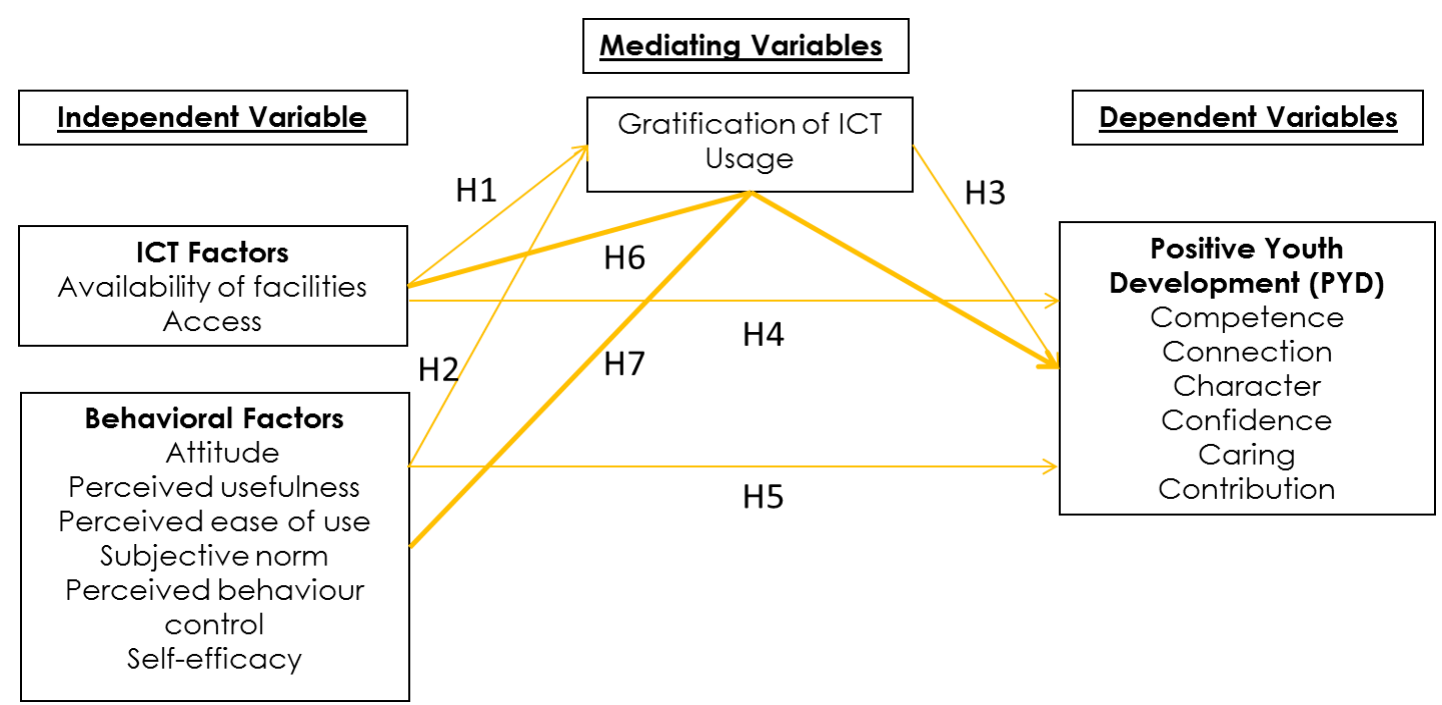

Figure 1: Factors that Influence Positive Youth Development in Rural Library 


\section{RESEARCH METHOD}

In conducting this study, a quantitative approach was employed by means of a survey. There were 30 items used to measure gratification of ICT usage. Another 30 items were used to measure PYD dimensions that was adapted from several studies (Omar et al. 2016; Samsuddin et al. 2016). These items were translated to the Malay language and five point Likert Scale option ranging from $1=$ strongly disagree to $5=$ strongly agree were used to gather the data as shown in the survey instrument (Appendix 1).

The study population is approximately 447,893 library patrons, based on data from membership record in Malaysian rural libraries. Based on this number, a total sample size is 399 (using Yamane's (1967) sampling calculation). A total of 16 rural libraries equipped with ICT services were selected in a multi-stage cluster sampling that includes four states (Perak Pahang, Melaka, and Pulau Pinang) which represents the Central, East, South and West zones in Peninsular Malaysia. A simple random sampling approach was used to gather the data by taking the first 25 library visitors as the respondents in each rural library. The data were collected by several trained enumerators who assisted the respondents in answering the survey. A total of 400 responses consisted library users aged between 15 to 40 years of age were gathered.

Structural equation modelling (SEM) was employed using a maximum likelihood methods of AMOS version 21 to examine the research framework. SEM were used in the analysis to measure individual constructs, the measurement model, and the structural model, in examining the direct and indirect relationships among constructs within selected combination of theories. The first step in data preparation in SEM for this study was by conducting Confirmatory Factor Analysis (CFA); while the second step in the measurement model examines the relationship between the observed variables and the latent variables of the model.

\section{Validity and Reliability}

The convergent validity of the constructs was evaluated by assessing the adequacy of factor loadings of items on the respective latent construct. The factor loading value should be more than 0.5 (Byrne 2010; Hair et al. 2010); Average Variance Extracted (AVE) value should be more than 0.5 (Fornell and Larcker 1981); and the level of Composite Reliability (CR) should be above 0.7 (Hair et al. 2010 and Kline 2011); as illustrated in Table 2. The results indicated all items exhibited high factor loadings ranged from 0.62 to 0.95 . The AVE value of all constructs ranged from 0.511 to 0.697 which exceeded the minimum criterion of 0.5 . With respect to construct reliability, values for all constructs ranged from 0.837 to 0.931 , above the suggested threshold of 0.7 , revealing the adequate internal consistency among items in each scale. Therefore, the convergent validity of all constructs was justified.

Discriminant validity refers to the extent in which a construct is truly distinct from other constructs (Hair et al. 2010). Problems occur when observed variables in each construct correlate more highly with variables outside their parent factors or when latent variable is better explained by some other observed variable. In this study the discriminant validity was examined by two methods of test to determine that the two constructs are not measuring the same thing: (a) All correlation coefficient between two constructs indicates lower than .90 and thus meet the discriminant validity (Fornell and Larcker 1981; Hair et al. 2010); and (b) results showed the value of square root of AVE for all latent constructs were higher than the correlation coefficient between the focal construct and other constructs. Therefore, the results established the discriminant validity of the constructs. This is shown in Appendix 2. 
Table 2: Descriptive statistics, AVE and CR of the Research Scales

\begin{tabular}{lccccccc}
\hline \multicolumn{1}{c}{ Variables } & $\begin{array}{c}\text { Initial } \\
\text { items }\end{array}$ & $\begin{array}{c}\text { Final } \\
\text { no. of } \\
\text { items }\end{array}$ & $\begin{array}{c}\text { Factor } \\
\text { loading } \\
\text { range } \\
(>.5)\end{array}$ & Mean & SD & $\begin{array}{c}\text { Average } \\
\text { Variance } \\
\text { Extracted } \\
\text { (AVE > 0.5) }\end{array}$ & $\begin{array}{c}\text { Construct } \\
\text { Reliability } \\
\text { (CR > 0.7) }\end{array}$ \\
\hline Competence & 5 & 3 & $.70-.80$ & 3.89 & .68 & .604 & .916 \\
Connection & 5 & 3 & $.71-.90$ & 3.87 & .77 & .623 & .905 \\
Character & 5 & 3 & $.74-.89$ & 3.90 & .76 & .658 & .931 \\
Confidence & 5 & 4 & $.76-.85$ & 3.98 & .72 & .663 & .928 \\
Caring & 5 & 3 & $.76-.83$ & 3.89 & .76 & .646 & .919 \\
Contribution & 5 & 3 & $.65-.88$ & 3.84 & .74 & .626 & .898 \\
ICT & 12 & 5 & $.67-.83$ & 3.25 & .86 & .547 & .837 \\
AT & 10 & 6 & $.64-.84$ & 3.69 & .71 & .522 & .885 \\
PU & 10 & 4 & $.63-.95$ & 4.03 & .76 & .697 & .918 \\
PEOU & 10 & 6 & $.63-.80$ & 3.72 & .70 & .528 & .887 \\
SN & 9 & 5 & $.64-.80$ & 3.58 & .73 & .556 & .868 \\
PBC & 18 & 7 & $.63-.86$ & 2.15 & .85 & .575 & .889 \\
SE & 5 & 3 & $.64-.82$ & 3.83 & .75 & .511 & .887 \\
GIU & 30 & 9 & $.62-.79$ & 2.28 & .97 & .529 & .864 \\
\hline
\end{tabular}

Note. ICT=ICT Factor, AT= Attitude, PU= Perceived usefulness, PEOU= Perceived ease of use, $\mathrm{SN}=$ Subjective norm, $\mathrm{PBC}=$ Perceived behaviour control, $\mathrm{SE}=$ Self efficacy, GIU=Gratification ICT Usage.

\section{Model Fitness of Measurement Model and Structural Model}

As suggested by Hair et al. (2010), 3 to 4 fit indices were used in order to provide adequate evidence of model fit. As shown in Table 3, the goodness of fit indices suggests a good fit of the overall measurement model of the data after eliminated some of the items. The results showed that the Comparative Fit Index (CFI) and Incremental Fit Index (IFI) were well above the acceptable level of 0.9 , and the value of relative chi-square was well below 5 which are indicative of an acceptable fit between hypothetical model and the collected data (Marsh and Hocevar 1985; Bentler 1990). In addition, the value of Root Mean Square Error of Approximation (RMSEA) was 0.046 which is unequivocal evidence of close fit. The structural model analysis was used to conduct the path analysis and test the hypothesis of the study.

The results of assessing the structural model fits indicated that the data fit the model. It shows that the fit indices such as IFI were above 0.90 the level of acceptability or recommended value (Bentler 1990; Hatcher 1994); CFI (0.900) and Tucker-Lewis Index (0.892) were very close to acceptable criterion above 0.90 ; related chi-square $\left(\chi^{2} / \mathrm{df}\right)$ was well below the cut off value of 5 which is an indicative of an acceptable fit between hypothetical model. The collected data and the RMSEA was 0.046 which is unequivocal evidence of close fit both below 0.08 (Byrne 2010) and 0.05 (Hu and Bentler 1999).

Table 3: Goodness of Fit Indices of Measurement and Structural Model

\begin{tabular}{|c|c|c|c|c|c|c|c|}
\hline Model & CMIN $\left(\chi^{2}\right)$ & $\left(\chi^{2} / d f\right)$ & GFI & CFI & IFI & TLI & RMSEA \\
\hline $\mathrm{MM}$ & $\begin{array}{l}3419.357 \\
(p=.000)\end{array}$ & 1.841 & .791 & .902 & .903 & .893 & .046 \\
\hline SM & $\begin{array}{c}3450 \\
(p=.000)\end{array}$ & 1.849 & .789 & .900 & .901 & .892 & .046 \\
\hline
\end{tabular}

Note. $\mathrm{MM}=$ measurement model, $\mathrm{SM}=$ structural model. 


\section{RESULTS}

\section{Demographics Information}

Of the 400 rural library users sampled, more than half of the respondents $(57.8 \%)$ have had completed at least their secondary education. With respect to the employment status, more than two-third (66.5\%) of the respondents were unemployed (students and housewives), and 33.5 percent of the respondents were employed. In terms of visiting frequency, 38.2 percent of the respondents visits the library two to five times a month, and some visit more than six times a month (38.2\%). About 34.3 percent earned approximately RM2001 and above per month, 22.5 percent were categorized receiving household income between RM1501 to RM2000, 31.3 percent were at RM801 to RM1500, and 12 percent of the respondents make less than RM800. Therefore, the average mean of household income was RM2301.87 monthly.

\section{Hypothesis Testing}

The maximum likelihood estimation technique was used to estimate the model. The results of the hypothesized path analysis of the structural model are presented in Table 4.

(a) H1: There is a significant relationship between ICT factors and gratification of ICT usage

The finding indicates that there is no significant relationship between ICT factors (ICT) ( $\beta=-$ $.114, p=.129)$, perceived usefulness (PU) $(\beta=-.109, p=.487)$, perceived ease of use (PEOU) $(\beta=-.010, p=.945)$, perceived behaviour control (PBC) $(\beta=.099, p=.339)$ and self-efficacy (SE) $(\beta=-.058, p=.885)$ and gratification of ICT usage.

Table 4: Regression Weights in the Direct Hypothesized Model

\begin{tabular}{lccc}
\hline Independent Variables & $\begin{array}{c}\text { Dependent } \\
\text { Variables }\end{array}$ & $\begin{array}{c}\text { Standardized Regression } \\
\text { weights Beta }\end{array}$ & P Value \\
\hline ICT & & -.114 & .129 \\
AT & & $.347^{*}$ & .021 \\
PU & GIU & -.109 & .487 \\
PEOU & & -.010 & .945 \\
SN & & $.263^{* *}$ & .006 \\
PBC & .099 & .339 \\
SE & & -.058 & .885 \\
& & & .332 \\
& Competence & .085 & .707 \\
GIU & Connection & .032 & .982 \\
& Character & -.002 & .835 \\
& Confidence & -.023 & .548 \\
& Caring & .068 & .392 \\
\hline
\end{tabular}

Note. ICT=ICT Factor, AT=Attitude, PU=Perceived usefulness, PEOU=Perceived ease of use, $S \mathrm{~N}=$ Subjective norm, $\mathrm{PBC}=$ Perceived behaviour control, $\mathrm{SE}=$ Self efficacy, GIU=Gratification ICT Usage. P value: ${ }^{* *}=<.01 ;^{*}=<.05$

b) $\mathrm{H} 2$ : There is a significant relationship between behavioural factors and gratification of ICT usage

There is a significant relationship between behavioural factors which are attitude (AT) ( $\beta=$ $.347, p=.021)$, and subjective norm (SN) $(\beta=.263, p=.006)$ and gratification of ICT usage. 
Therefore, based on the structural model, $\mathrm{H} 1$ was not supported, while $\mathrm{H} 2$ was partially supported with two factors which are AT and SN. Thus, 34 percent AT towards ICT usage relates to gratification of ICT usage with a positive effects. While 26 percent of SN related to gratification of ICT usage with a positive effects.

The findings suggest as the level of attitude towards ICT usage increases, the level of gratification of ICT usage would also increase. This is in line with Omar et al. (2012) who reported attitude plays an important role in creating a better usage of rural library services. Shiro (2008) also mentioned rural community have a positive attitude towards government projects and programmes such as ICT facilities provision as shown in a higher level of usage on services provided. As the level of subjective norm increases, the level of gratification of ICT usage would also increase. A positive level of subjective norm among the rural community encourages the usage of ICT services among rural youth as provided in the rural library that later gratify their needs. In other words, subjective norm which is also categorized as community characteristics can influence the local services such as ICT services in rural library to be fully utilized and sustain by the community itself (Samah et al. 2013).

c) H3: There is a significant relationship between gratification of ICT usage and PYD

The results in Table 5 revealed that gratification of ICT usage has no significant relationship with any of $6 C^{\prime}$ 's dimensions of PYD: competence $(\beta=.085, p=.332)$, connection ( $\beta=.032$, $p=.707)$, character $(\beta=-.002, p=.982)$, confidence $(\beta=-.023, p=.835)$, caring $(\beta=.068, p$ $=.548)$, and contribution $(\beta=.084, p=.392)$. Hence, $\mathrm{H} 3$ was not supported by the results of SEM analysis.

The finding refutes the study by Joorabchi, Hassan and Osman (2013) who reported a significant result on five PYD dimensions (Competence, Connection, Character, Confidence, and Caring)

Gratification of ICT usage did not contribute to any of the $6 C^{\prime}$ s dimensions of PYD among rural youth community which leads to their positive development. This suggests that the respondents did not solely depend on ICT factors probably due to persistently practicing conventional life style. ICT is probably used as an alternative facility to develop new skills and support their daily information tasks but it is not mandatory compared to their counterpart in urban area who often reported on ICT (smartphones and gadgets) dependency.

Table 5 shows the results of gratification of ICT usage as a direct path and mediating effects between ICT factors and behavioural factors (attitude, perceived usefulness, perceived ease of use, subjective norm, perceived behaviour control, and self-efficacy) on $6 \mathrm{C}^{\prime}$ 's dimension of PYD (Competence, Connection, Character, Confidence, Caring and Contribution).

Table 5: Gratification of ICT Usage as Mediating Effect

\begin{tabular}{lcccccccc}
\hline & & & & & & & & \\
IV & DV & $\begin{array}{c}\text { Direct } \\
\text { effect }\end{array}$ & \multirow{2}{*}{$\begin{array}{c}\text { Total } \\
\text { effects }\end{array}$} & $\begin{array}{c}\text { Indirect } \\
\text { effect }\end{array}$ & & $\begin{array}{c}95 \% \text { Bootstrap BC } \\
\text { Cl }\end{array}$ & \multicolumn{2}{c}{$\begin{array}{c}\text { Hypothesized } \\
\text { Relationship }\end{array}$} \\
\cline { 6 - 9 } & & & & LB & UB & Direct & Mediate \\
\hline ICT & & -.067 & .057 & .000 & -.045 & .032 & $X$ & $X$ \\
AT & Competence & -.104 & $-.385^{*}$ & .000 & -.051 & .133 & $X$ & $X$ \\
PU & & -.217 & -.153 & .000 & -.029 & .029 & $X$ & $X$
\end{tabular}


Samsuddin, S.F., Omar, S.Z. \& Shaffril, H.A.M.

\begin{tabular}{|c|c|c|c|c|c|c|c|c|}
\hline \multirow[t]{2}{*}{ IV } & \multirow[t]{2}{*}{ DV } & \multirow[t]{2}{*}{$\begin{array}{l}\text { Direct } \\
\text { effect }\end{array}$} & \multirow[t]{2}{*}{$\begin{array}{c}\text { Total } \\
\text { effects }\end{array}$} & \multirow[t]{2}{*}{$\begin{array}{l}\text { Indirect } \\
\text { effect }\end{array}$} & \multicolumn{2}{|c|}{$\begin{array}{c}\text { 95\% Bootstrap BC } \\
\mathrm{Cl} \\
\end{array}$} & \multicolumn{2}{|c|}{$\begin{array}{c}\text { Hypothesized } \\
\text { Relationship }\end{array}$} \\
\hline & & & & & LB & UB & Direct & Mediate \\
\hline PEOU & & -.272 & -.209 & .000 & -.048 & .020 & $x$ & $\mathrm{x}$ \\
\hline SN & & .158 & .033 & .000 & -.052 & .084 & $x$ & $x$ \\
\hline PBC & & .183 & $.332 * *$ & .000 & -.029 & .026 & $x$ & $x$ \\
\hline SE & & $1.281 * *$ & $1.543^{* *}$ & .000 & -.012 & .000 & v & $x$ \\
\hline ICT & & .032 & .030 & .003 & -.031 & .052 & $x$ & $\mathrm{x}$ \\
\hline AT & Connection & $-.301 *$ & $-.394 *$ & -.008 & -.067 & .120 & v & $x$ \\
\hline PU & & -.107 & -.302 & .002 & -.023 & .054 & $x$ & $x$ \\
\hline PEOU & & -.219 & -.319 & .000 & -.036 & .026 & $x$ & $x$ \\
\hline SN & & .173 & .076 & -.006 & -.067 & .073 & $x$ & $x$ \\
\hline PBC & & $.307 * *$ & $.361^{* *}$ & -.002 & -.050 & .018 & v & $x$ \\
\hline SE & & $1.206 * *$ & $1.702^{* *}$ & .001 & -.007 & .000 & v & $x$ \\
\hline ICT & & .058 & .103 & -.008 & -.109 & .013 & $x$ & $x$ \\
\hline AT & Character & $-.387^{*}$ & $-.391 *$ & .024 & -.033 & .213 & v & $x$ \\
\hline PU & & -.147 & $-.520 * *$ & -.007 & -.065 & .010 & $x$ & $x$ \\
\hline PEOU & & -.210 & -.279 & -.001 & -.058 & .024 & $x$ & $x$ \\
\hline SN & & .032 & .057 & .018 & -.033 & .142 & $x$ & $x$ \\
\hline PBC & & $.332 * *$ & $.358 * *$ & .007 & -.011 & .052 & v & $x$ \\
\hline SE & & $1.541^{* *}$ & $1.716^{* *}$ & -.004 & -.108 & .031 & $v$ & $x$ \\
\hline ICT & & .032 & .032 & -.004 & -.071 & .013 & $x$ & $x$ \\
\hline AT & Confidence & $-.400 *$ & $-.303^{*}$ & .012 & -.035 & .148 & v & $x$ \\
\hline PU & & -.295 & -.111 & -.004 & -.049 & .011 & $x$ & $x$ \\
\hline PEOU & & -.319 & -.217 & .000 & -.043 & .017 & $x$ & $x$ \\
\hline SN & & .074 & .174 & .009 & -.031 & .093 & $x$ & $x$ \\
\hline PBC & & $.360 * *$ & $.307^{* *}$ & .003 & -.011 & .040 & v & $x$ \\
\hline SE & & $1.700 * *$ & $1.209 * *$ & -.002 & -.068 & .033 & v & $x$ \\
\hline ICT & & .105 & -.068 & -.010 & -.084 & .004 & $x$ & $x$ \\
\hline AT & Caring & $-.404 *$ & -.102 & .030 & -.012 & .165 & v & $x$ \\
\hline PU & & $-.511 * *$ & -.219 & -.009 & -.052 & .008 & v & $x$ \\
\hline PEOU & & -.278 & -.272 & -.001 & -.036 & .04 & $x$ & $x$ \\
\hline SN & & .055 & .158 & .022 & -.010 & .112 & $x$ & $x$ \\
\hline PBC & & $.356 * *$ & .183 & .008 & -.007 & .040 & v & $x$ \\
\hline SE & & $1.717^{* *}$ & $1.281^{* *}$ & -.006 & -.170 & .038 & v & $x$ \\
\hline ICT & & .015 & .013 & -.010 & -.110 & .009 & $x$ & $x$ \\
\hline AT & Contribution & -.290 & -.283 & .030 & -.025 & .201 & $x$ & $x$ \\
\hline PU & & -.170 & -.176 & -.009 & -.062 & .011 & $x$ & $x$ \\
\hline PEOU & & -.425 & $-.425^{*}$ & -.001 & -.044 & .031 & $x$ & $x$ \\
\hline SN & & .177 & .178 & .022 & -.022 & .148 & $x$ & $x$ \\
\hline PBC & & $.340 * *$ & $.341 * *$ & .008 & -.010 & .049 & v & $\mathrm{x}$ \\
\hline SE & & $1.471 * *$ & $1.470 * *$ & -.005 & -.155 & .041 & v & $x$ \\
\hline
\end{tabular}

Note: $\mathrm{BC}=$ Bias - corrected confidence interval; 5,000 bootstrap samples was requested; ICT=ICT Factor, $\mathrm{AT}=$ Attitude, $\mathrm{PU}=$ Perceived usefulness, $\mathrm{PEOU}=$ Perceived ease of use, $\mathrm{SN}=$ Subjective norm, $\mathrm{PBC}=\mathrm{Perceived}$ behaviour control, $\mathrm{SE}=$ Self efficacy. $\mathrm{P}$ value: ${ }^{* *}=<.01{ }^{*}=<.05$ 
d) H4: There is a significant relationship between ICT factors and 6C's dimension of PYD

The results indicated that ICT factors have no significant relationship with any of $6 C^{\prime}$ s dimensions of PYD, namely Competence $(\beta=-.067, p=.530)$, Connection $(\beta=.032, p=.762)$, Character $(\beta=.058, p=.636)$, Confidence $(\beta=.032, p=.813)$, Caring $(\beta=.105, p=.447)$, and Contribution $(\beta=.015, p=.903)$. Therefore, $\mathrm{H} 4$ was not supported.

e) $\mathrm{H} 5$ : There is a significant relationship between behavioural factors and $6 \mathrm{C}^{\prime}$ s dimension of PYD

$\mathrm{H} 5 \mathrm{a}$ : There is a significant relationship between behavioural factors on Competence

There is a significant relationship between SE and competence $(\beta=1.281, p=.000)$. Therefore, based on the structural model the $\mathrm{H} 5 \mathrm{a}$ was supported only on one factor which is self-efficacy.

$\mathrm{H} 5 \mathrm{~b}$ : There is a significant relationship between behavioural factors on Connection.

The is a significant relationship between AT ( $\beta=-.301, p=.047), \operatorname{PBC}(\beta=.307, p=.002)$, and SE $(\beta=1.206, p=.000)$ and connection. $\mathrm{H} 5 \mathrm{~b}$ was supported only by three behavioural factors (AT, PBC, and SE).

$\mathrm{H} 5 \mathrm{c}$ : There is a significant relationship between behavioural factors on Character. There is a significant relationship between AT $(\beta=-.387, p=.028)$, PBC $(\beta=.332, p=.004)$, and $S E(\beta=1.541, p=.000)$ and character. $H 5 c$ is supported by three behavioural factors (AT, $\mathrm{PBC}$, and $\mathrm{SE})$.

$\mathrm{H} 5 \mathrm{~d}$ : There is a significant relationship between behavioural factors on Confidence.

The is a significant relationship between AT ( $\beta=-.400, p=.037), \operatorname{PBC}(\beta=.360, p=.004)$, and SE $(\beta=1.700, p=.000)$ confidence. $\mathrm{H} 5 \mathrm{~d}$ is supported by three behavioural factors (AT, PBC, and $\mathrm{SE})$.

H5e: There is a significant relationship between behavioural factors on Caring

There is a significant relationship between AT $(\beta=-.404, p=.041), P U(\beta=-.511, p=.008)$, PBC $(\beta=.356, p=.006)$, and SE $(\beta=1.717, p=.000)$ and caring. H5e is supported by four behavioural factors (AT, PU, PBC, and SE)

H5f: There is a significant relationship between behavioural factors on Contribution There is a significant relationship between PBC $(\beta=.340, p=.003)$ and SE $(\beta=1.471, p=$ .000 ) and contribution. $\mathrm{H} 5 \mathrm{f}$ is supported by two behavioural factors (PBC, SE)

The results revealed that attitude, perceived usefulness, and perceived behaviour control had a significant direct relationship with certain $6 C^{\prime}$ 's dimension of PYD. Self-efficacy was significantly and positively associated with all the $6 C^{\prime}$ 's dimension of PYD (Competence, Connection, Character, Confidence, Caring, and Contribution).

Bootstrapping approach was used in this study to examine possible mediation effect of gratification of ICT usage in relationship between ICT factors and behavioural factors and $6 C^{\prime}$ 's dimension of PYD. Bootstrapping method provides an estimation of the magnitude and significance of indirect effect. However, 5,000 bootstrap samples were required as recommended by Hayes (2009) and 95\% confidence intervals (CI) for Bias-corrected option. 
If the result shows a zero value is not between the lower and upper bound, the indirect effect is not significant.

H6: There is a significant relationship between ICT factors and $6 C^{\prime}$ s dimension of PYD, mediated by gratification of ICT usage.

Table 6 shows the Standardized Indirect Effect (SIE) of ICT factor on 6C's dimension of PYD through the mediation of gratification of ICT usage was not significant, which Competent ( $\beta$ $=.000, p=.931)$, Connection $(\beta=.003, p=.607)$, Character $(\beta=-.008, p=.373)$, Confidence $(\beta=-.004, p=.492)$, Caring $(\beta=-.010, p=.182)$, Contribution $(\beta=-.010, p=.264)$. Therefore $\mathrm{H} 6$ is not supported.

H7: There is a significant relationship between behavioural factors and $6 C^{\prime}$ s dimension of PYD, mediated by gratification of ICT usage.

The findings revealed that the Standardized Indirect Effect (SIE) of behavioural factors (attitude, perceived usefulness, perceived ease of use, subjective norm, perceived behaviour control and self-efficacy) on 6C's dimension of PYD through the mediation of gratification of ICT usage in rural library among rural youth was not significant. Therefore $\mathrm{H} 7$ is not supported. This contradicted with previous study done by Joorabchi et al. (2013), who reported gratification of Internet usage mediates the relationship between behaviour factors (attitude) and PYD.

\section{DISCUSSIONS}

Providing adequate ICT infrastructure and access to the rural community would affect users' satisfaction and leading to their positive behavioural outcome as reported by Bashir et al. (2011). However, finding of this study shows otherwise. This is possibly because most rural residential areas nowadays have access to the Internet and the residents are equipped with their own ICT facilities at homes (Omar et al. 2012). This might also be due to the existence of several programmes or activities conducted in rural libraries, apart from having ICT facilities, that might be useful in developing personal youth development amongst rural youth.

Positive attitude would lead to positive self-development in building good relationship among family members, friends and other people in the surroundings. Positive characters such as being a matured youth in handling tasks and solving problems, having confidence in facing communities and sense of caring towards others would create a better individual (Lerner 2004). Omar et al. (2012) has also reported positive attitude as one of the factors related to rural library services that play an important role in creating better usage of the library. The negative correlation as reported from this study indicates that once youth's attitude towards ICT usage is positive, they might develop negative effects such as addiction and dependency on the Internet and social media as indicated by Munoz-Miralles et al. (2016). This would have an impact on social communication, changes in character, less selfconfidence, and less sense of caring among family members.

In terms of perceived usefulness on ICT usage, there was a similar relationship between caring in PYD. Although the youth could share knowledge and feelings with others while they are surfing the websites and connecting via Facebook, the respondents do not perceive that using social networks was useful and could bring benefits to others. Yusliza et al. (2009) and 
Ramayah (2006) have proven that the level of ICT usage would be higher if the services were useful to them. The negative relationship in this study could be related to less sense of caring if someone has higher perceived usefulness on ICT usage such as being free to condemn, hack and immorally stalk others using social media tools. Meanwhile, the higher level of perceived ease of use of ICT in the rural library among the rural youth leads to a decrease in the contribution of PYD. This result somehow differs with Joorabchi, Hassan and Osman (2013) which reported that subjective norms have influenced on PYD in Competence, Connection, Character, Confidence, Caring, and Contribution. Subjective norms, which is similar to social influence, have shown that in PYD, rural youth nowadays tend to be more prepared and matured in making decision. They could clearly differentiate good and bad without the influence of family members, friends and their surroundings. This was supported by Lerner et al. (2005), who described that youth would develop positively when their ecology encourages their positive outcomes such as community contribution and engaging citizenship. Lerner et al. (2005) also mentioned that once youth have mutual beneficial relations with their surroundings (people and institutions), they would be influenced positively in contribution (self, family, community, and civil society). However, although subjective norms were significantly approved in previous studies (Spencer 2000; Hildreth 2007) as contributors in influencing rural library services usage, the current study has demonstrated rural youth have less relation to the $6 C^{\prime}$ 's of PYD dimensions.

Perceived behaviour control is highly related to rural PYD, in terms of ICT usage. Indirectly the rules and regulations in rural library have disciplined the youth community to use ICT wisely. Although the level of perceived behaviour control is low, it is in positive relationships with PYD among rural youth community, which explained that rural youth are not fully depending on ICT like their urban counterparts. ICT facilities and services provided by rural libraries were not merely important in developing positive attitude among the youth. This corroborated with Omar et al. (2012) who reported that the main purpose of rural youth visit to the libraries was not because of the ICT facilities and services but to find reading materials and as a meeting or community gathering place. Several previous studies argued that ICT was the main motivation among rural youth to visit the libraries (McQuaid, Lindsay, and Greig 2004; Tenopir et al. 2009; Alexapolous, Koutsouris and Tzouramani 2010).

Self-efficacy is a perception on one's ability to solve task and achieve goal (Sainz and Eccles 2012). Digital competence, the ability to solve problems, the confidence in using technology, and leadership character are the positive impacts that were found to be correlated with selfefficacy towards PYD in the current study. This is in agreement with several other studies conducted (Yang and Cheng 2009; Devolder, van Braak, and Tondeur 2012; Hatlevik, Guðmundsdóttir and Loi 2014) that concluded rural youth have to be prepared in developing their inner strength towards positive level of self-efficacy to face challenges in the future.

Although Joorabchi, Hassan and Osman (2013) reported a positive mediation effect on gratification of Internet usage among urban youth that includes university students as the respondents, this is in contrast with the current study. One of the reasons is probably due to the different setting and surroundings taken place in the study. The rural community under investigation were not fully depending on the Internet in their daily task. They are still practicing casual conversation among friends and ask opinion from the elderlies and develop themselves through best practice reflected by their parents and teachers. Furthermore, when the youth communicate well and involve themselves in positive activities with the adults, these would positively impact their development, sustain adult-youth relationship, build skills, promote leadership abilities and strengthen ties in the communities (Eccles and Gootman 2002; Lerner 2004). In addition, such community based programmes would 
facilitate the growth and accentuate the youth strengths and at the same time enhanced the $6 C^{\prime}$ 's of PYD among rural youth community (Roth and Brooks-Gunn 2003).

Although there were a few arguments among researchers from previous studies (McQuaid, Lindsay, and Greig 2004; Kuate 2008; Tenopir et al. 2009; Alexapolous, Koutsouris and Tzouramani 2010; Norshila, Masitah and Wan Nor Haliza 2011) that the main purpose of youth using rural library services is mainly for seeking information using computer and the Internet, but within the context of this study, gratification of ICT usage was not supported as mediating effect towards PYD among rural youth community. The information seeking behaviour which has significantly changed among youth (Tenopir et al. 2009) has not affected them when it comes to rural library as a place to access information sources. If they have preference to seek virtual information elsewhere, there are other options of information service platforms in rural areas, such as telecentres, wireless village services, cybercafés, Rural Internet Centres, Medan Infodesa and Community Broadband Centres which are available across the country (Omar et al. 2012). These ICT centres may offer an alternative way for the rural youth to gain experience and skills in using ICT successfully which indirectly would have significance towards their PYD and search for livelihood as they transition into adulthood.

\section{CONCLUSION}

This research focuses on the gratification of ICT usage as mediating effect on PYD in rural library setting. Although the mediating variable was reported in previous studies to have a positive effect on the urban community, this study has evidence that the gratification of ICT usage as mediating effect in the rural community for PYD is insignificant. However, ICT services in rural library should be continued in the future to narrow the gap of digital divide among the rural community. This study has provided a better understanding on the factors that could influence PYD in rural areas. Consequently, intervention programmes to promote positive youth development in the lens of the $6 \mathrm{C}^{\prime} \mathrm{s}$ dimensions (Competence, Connection, Character, Confidence, Caring and Contribution) could be embraced to reduce problematic behaviours among youth either in urban or rural areas.

For future research, this study could be carried out in a wider range of population taking consideration to use census sampling approach. Broadening the setting might result in getting different results and would be better in generalising the findings. Furthermore, apart from rural library as a place of ICT provisions, other telecentres in rural areas such as 1 Malaysia Internet Centre (PI1M) can be considered as the location to be studied.

\section{ACKNOWLEDGEMENT}

This research was conducted under Putra Grant - Putra Graduate Initiative (IPS), Universiti Putra Malaysia and with cooperation from Perpustakaan Negara Malaysia (PNM) Research Department.

\section{REFERENCES}

Ajzen, I. 1991. The theory of planned behavior. Organization Behavior and Human Decision Processes, Vol.50, no.2: 179-211. 
Alexapolous, G., Koutsouris, A., and Tzouramani, I. 2010. Adoption and use of ICTs among rural youth: Evidence from Greece. International Journal of Information Communication Technologies and Human Development, Vol.3: 1-18.

Ang, M. 2009. Positive youth development in Malaysia: A dissertation in human development and family studies (Ph.D thesis). The Pennsylvania State University, Pennsylvania State, United States of America.

Bashir, M. S., Samah, B. A., Emby, Z., Badsar, M., Shaffril, H. A. M., and Aliyu, A. 2011. Information and communication technology development in Malaysia: Influence of competency of leaders, location, infrastructures and quality of services on telecentre success in rural communities of Malaysia. Australian Journal of Basic and Applied Science, Vol.5, no.9: 1718-1728.

Bean, G., Winzeler, A. and Baber, K. 2005. Positive Youth Development. UNH Center on Adolescence. K Baber, UNH Director New Hampshire: University of New Hampshire. Available at: https://chhs.unh.edu/sites/chhs.unh.edu/files/docs/fs/ adolescent_resources/Positive_Youth_Development.pdf

Bentler, P. M. 1990. Comparative fit indexes in structural models. Psychological bulletin, Vol. 107, no.2: $238-246$.

Bers, M. U. 2006. The role of new technologies to foster positive youth development. Applied Developmental Science, Vol.10, no.4: 200-219.

Bertot, J. C., McClure, C. R., Wright, C. B., Jensen, E., and Thomas, S. 2009. Public libraries and the Internet 2009: Survey results and findings. Information Institute and Center for Library \& Information Innovation. Available at: http://ipac.umd.edu/sites/default/ files/publications/2009_plinternet.pdf

Bolong, J., Omar, S. Z., Shaffril, H. A. M., D'Silva, J. L. and Hassan, M. A. 2013. ICT and its implication on fishermen income in Malaysia. International Business Management, Vol.7, no.2: 78-83.

Brown, B. B. 2005. Moving forward with research on adolescence: Some reflections on the state of JRA and the state of the field. Journal of Research on Adolescence, Vol.15, no.4: 657-673.

Byrne, B. M. 2010. Structural equation modelling with Amos: basic concepts, application, and programming $\left(2^{\text {nd }}\right.$ ed.). New York: Routledge.

Caldwell, L. L. and Smith, E. A. 2006. Leisure as a context for youth development and delinquency prevention. Australian \& New Zealand of Criminology, Vol.39, no.3: 398 418.

Cowen, E. L. 2000. Psychological wellness: Some hopes for the future. In D. Cicchetti, J. Rappaport, I.N. Sandler, and R. P. Weissberg (Eds.), The Promotion of wellness in children and adolescents (pp. 477-503). Washington, DC: Child Welfare League of America Press.

Damon, W. 2004. What is Positive Youth Development?, Annals of the American Academy of Political and Social Science, Vol. 591, no.1: 13- 24.

Davis, F.D., Bagozzi, R.P., and Warshaw, P.R. 1989. Use acceptance of computer technology: A comparison of two theoretical models. Journal of Management Science, Vol. 35: 9821003.

Devolder, A., van Braak, J., and Tondeur, J. 2012. Supporting self-regulated learning in computer-based learning environments: systematic review of effects of scaffolding in the domain of science education. Journal of Computer Assisted Learning, Vol.28, no.6: 557 - 573. Available at: https://doi.org/10.1111/j.1365-2729.2011.00476.x

Eagly, A. H., and Chaiken, S. 1993. The psychology of attitudes. Orlando, FL: Harcourt Brace Jovanovich College Publishers. 
Eccles, J., and Gootman, J. A. 2002. Community programs to promote youth development. Committee on community-level programs for youth. National Academy Press: Washington.

Elbert, C. D. and Alston, A. J. 2005. An evaluative study of the United States cooperative extension service's role in bridging the digital divide. Journal of Extension, Vol. 43, no. 5. Available at: http://www.joe.org/joe/2005october/rb1.php

Fornell, C., and Larcker, D. F. 1981. Evaluating structural equation models with unobservable variables and measurement error. Journal of Marketing Research, Vol.18, no.1: 39-50.

Goulding, A. 2008. Libraries and cultural capital. Journal of Librarianship and Information Science, Vol.40, no.4: 235-237.

Hair, J. F., Black, W. C., Babin, B. J. and Anderson, R. E. 2010. Multivariate data analysis $\left(7^{\text {th }}\right.$ ed.). Englewood Cliffs, N.J.: Pearson Prentice Hall.

Hassan, M. A., Ismail, N., Omar, S.Z. and Bolong, J. 2008. Impact of ICT projects on participants in the rural areas. Pertanika Journal of Social Sciences \& Humanities, Vol.16: 85-94.

Hassan, M. A., Samah, B. A., Shaffril, H. A. M., and D'Silva, J. L. 2011. Perceived usefulness of ICT usage among JKKK members in Peninsular Malaysia. Asian Social Science, Vol.7, no.10: 255-266.

Hatcher, L. 1994. A step-by-step approach to using the SAS system for factor analysis and structural equation modelling. The SAS Institute: Cary, NC. Review: 325-339.

Hatlevik, O. E., Guðmundsdóttir, G. B., and Loi, M. 2014. Digital diversity among upper secondary students: a multilevel analysis of the relationship between cultural capital, self-efficacy, strategic use of information and digital competence. Computers \& Education, Vol.81: 345-353. Available at: 10.1016/j.compedu.2014.10.019

Hayes, A. F. 2009. Beyond Baron and Kenny: Statistical mediation analysis in the new millennium. Communication Monographs. Vol.79, no.4: 408-420. Available at: https://doi.org/10.1080/03637750903310360

Hildreth, S. 2007. Rural libraries: the heart of our communities. Available at: http://arsl.pbworks.com/f/Article+-+Rural+Libraries+by+Hildreth+Public+Libraries+Mar Apr+07.pdf

$\mathrm{Hu}$, L., and Bentler, P. M. 1999. Cut off criteria for fit indexes in covariance structure analysis: Conventional criteria versus new alternatives. Structural Equation Modeling: $A$ Multidisciplinary Journal, Vol.6, no.1: 1-55.

Hu, P. J., Clark, T. H. K., and Ma, W. W. 2003. Examining technology acceptance by school teachers: A longitudinal study. Information and Management, Vol.41, no.2: 227-241.

Ismail, A., Ahmad, N., and Affandy, H. B. 2013. The use of ICT in rural school libraries. Journal of Asian Scientific Research, Vol.3, no.6: 587 - 599.

Joorabchi, T. N., Hassan, M. S. and Osman, M. N. 2013. Relationship between Internet usage and Positive Youth Development in Malaysia. SEARCH: The Journal of South East Asia Research Centre for Communication and Humanities, Vol.5, no.2: $37-64$.

Katz, E., Blumler, J., and Gurevitch, M. 1974. Utilization of mass communication by the individual. In J. Blumler and E. Katz (Eds.), The uses of mass communication: Current perspectives on gratifications research (pp. 19-34). Sage: Beverly Hills, CA.

Klein, J. D., Sabaratnam, P., Auerbach, M., Smith, S. M., Kodjo, C., Lewis, K., Ryan, S. and Dandino, C. 2006. Development and factor structure of a brief instrument to assess the impact of community programs on Positive Youth Development: The Rochester Evaluation of Asset Development for Youth (READY) Tool. Journal of Adolescent Health, Vol.39: 252- 260.

Kline, R. B. 2011. Principles and practice of structural equation modeling (3rd ed.). New York: Guilford Press. 
Kuate, F.A.F. 2008. The social impact of ICTs on youth living in less developed countries: a case study of the mobile phone in Cameroonian rural areas. Paper presented at The Fourth International Conference on Technology, Knowledge and Society, 18-20 January, 2008. Boston.

Kumar, N., Rose, R. C. and D'Silva, J. L. 2009. Factors influencing the effective use of technology among Malaysian teachers. European Journal of Social Sciences, Vol.6: 108124.

Lerner, R. M., Lerner, J., Almerigi. J., Theokas, C., Phelps, E., Gestsdottir, S., . . von Eye, A. 2005. Positive Youth Development, participation in community youth development programs, and community contributions of fifth-grade adolescents findings from the first wave of the 4-h study of positive youth development. The Journal of Early Adolescence, Vol.25, no.1: 17-71.

Lerner, R. M. 2004. Liberty: Thriving and civic engagement among America's youth. Beverly Hills: Sage.

Malaysian Communication and Multimedia Commission (MCMC). 2014. Internet Users Survey 2012. Available at: http://www.skmm.gov.my/facts_figures/stats/index.asp

Malaysian Communication and Multimedia Commission (MCMC). 2016. Internet Users Survey 2016. Available at: http://www.skmm.gov.my/facts_figures/stats/index.asp

Marsh, H. W., and Hocevar, D. 1985. Application of confirmatory factor analysis to the study of self-concept: First- and higher order factor models and their invariance across groups. Psychological Bulletin, Vol.97: 562-582.

Mazuki, R., Omar, S. Z., D'Silva, J. L., Shaffril, H. A. M., and Bolong, J. 2014. Mapping the problems in using the rural library services among rural youth in Malaysia. Proceeding of the Social Sciences Research ICSSR 2014, 156-163. Kota Kinabalu Sabah, Malaysia.

McQuaid, R., Lindsay, C., and Greig, M. 2004. 'Reconnecting' the unemployed information and communication technology and services for jobseekers in rural areas. Information, Communication and Society, Vol.7, no.3: 364-388.

Ministry of Youth and Sports Malaysia (KBS). 1997. National Youth Development Policy. Available at: http://www.youthpolicy.org/national/Malaysia_1997_National_Youth_ Development_Policy.pdf

Moore, K. A., Lippman, L., and Brown, B. 2004. Indicators of child well-being: The promise for positive youth development. Annals of the American Academy of Political and Social Science, Vol.591: 125-145.

Muhammad, R. 2004. Levels of Information Technology (IT) applications in Muslim world libraries. Journal of the Electronic Library, Vol.22, no.3: 273-80.

Munoz-Miralles, R., Ortega-Gonzalaez, R., Lopez-Moron, M. R., Batalla-Martinez, C., Manresa, J. M., Montella-Jordana, N., Chamarro, A., Carbonell, X. and Toran-Monserrat, P. 2016. The problematic use of Information and Communication Technologies (ICT) in adolescents by the cross sectional JOITIC study. BMC pediatrics, Vol.16, no.1: 140.

National Library of Malaysia (NLM). 2015. Bahagian Penyelidikan, Perpustakaan Negara Malaysia. Kuala Lumpur: Perpustakaan Negara Malaysia.

Norshila, S., Masitah, A., and Wan Nor Haliza, W. M. 2011. Rural youth's perceptions of information sources and rural library services. Available at: http://unllib.unl.edu/LPP/shaifuddin-ahmad-mokhtar.htm

Omar, S. Z., Shaffril, H. A. M., Bolong, J. and D'Silva, J.L. 2012. The impingement factors of rural library services usage among rural youth in Malaysia. Asian Social Science, Vol.8, no.7: 60-68.

Omar, S. Z., Shaffril, H.A.M., D'Silva, J.L., Bolong, J., and Hamzah, A. 2014. Mapping the patterns and problems in using rural library services among rural youth in Malaysia. Information Development: 1-12. Available at: idv.sagepub.com/content/early/ 2014/01/08/0266666913515506.full.pdf 
Omar, S. Z., Mazuki, R., Bolong, J., D'Silva, J.L., and Shaffril, H. A. M. 2016. Pattern of Internet usage at the rural library among rural youth in Malaysia. Mediterranean Journal of Social Sciences, Vol.7, no.1: 91 - 95. Available at: DOI:10.5901/mjss.2016.v7n1s1p91

Ramayah, T. 2006. Interface characteristics, perceived ease of use and intention to use an online library in Malaysia. Information Development, Vol.22, no.2: 123 - 133.

Roth, J. L. and Brooks-Gunn, J. 2003. What is a youth development program? Identification and defining principles. In. F. Jacobs, D. Wertlieb, and R. M. Lerner (Vol. Eds.), Enhancing the life chances of youth and families: Public service systems and public policy perspectives: Vol. 2. Handbook of applied developmental science: Promoting positive child, adolescent, and family development through research, policies, and programs (pp. 197-223). Thousand Oaks, CA: Sage.

Rubin, A. M. 1984. Ritualized and instrumental television viewing. Journal of Communication, Vol.34, no.3: 67-77.

Sainz, M. and Eccles, J. 2012. Self-concept of computer and math ability: Gender implications across time and within ICT studies. Journal of Vocational Behavior, Vol.80: 486-499.

Samah, B. A., Shaffril, H. A. M., Hassan, M. A. and D'Silva, J. L. 2011. Can Technology Acceptance Model be applied on the rural setting: The case of village development and security committee in Malaysia. Journal of Social Sciences, Vol.7, no.2: 113-119. Available at: http://dx.doi.org/10.3844/jssp.2011.113.119

Samah, B. A., Badsar, M., Abu Hassan, M., Osman, N., and Shaffril, H.A.M. 2013. Youth and telecenters in community building in rural Peninsular Malaysia. Pertanika Journal of Social Science and Humanities, 21, 67-78.

Samsuddin, S. F., Bolong, J., Omar, S. Z., D'Silva, J. L., Sahharon, H. and Shaffril, H. A. M. 2015. Examining the impact of demographic factors on the attitude of rural communities in Malaysia towards village Wifi services. Asian Social Science, Vol.11, no.18: 134-143. Available at: http://dx.doi.org/10.5539/ass.v11n18p134

Samsuddin, S. F., Omar, S. Z., Samah, B. A. and Bolong, J. 2016. Potential Benefits of ICT towards Rural Positive Youth Development in Malaysia. International Journal of Academic Research in Business and Social Sciences, Vol.6, no.5: 258- 272.

Shaffril, H. A. M., Omar, S. Z., Hassan, M. A., Bolong, J. and D'Silva, J. L. 2012. Measuring ICT Usage among West Coast Fishermen: Pre-Test Results from Port Dickson, Negeri Sembilan. American Journal of Agricultural and Biological Sciences, Vol.7, no.1: 21-27.

Shiro, U. 2008. A case study of DIY ICT. Information, Vol.10, no.4: 46-60.

Soontiens, W., Miyamoto, T., Egan, V., Schapper, P., McDermont, D., Vargas, J. E. 2007. Mulitlateral development bank international survey of e-procurement systems. World Bank, Washington, DC. Available at https://openknowledge.worldbank.org/handle/ 10986/19014.

Spencer, R. M. 2000. The rural library in an urban environment: A study of the Brown County Public Library. Rural Libraries, Vol.20: 7-32.

Tenopir, C., King, D. W., Edwards, S. H., and Wu, L. 2009. Electronic journals and changes in scholarly article seeking and reading patterns. Aslib Proceedings, Vol.61, no.1: 5-32. Available at: http://dx.doi.org/10.1108/00012530910932267

The Asia Foundation. 2012. The youth factor: 2012 Survey of Malaysian youth opinion. The Asia Foundation.

Theokas, C., Almerigi, J. B., Lerner, R. M., Dowling, E. M., Benson, P. L., Scales, P. C., von Eye, A. 2005. Conceptualizing and modeling individual and ecological asset components of thriving in early adolescence. Journal of Early Adolescence, Vol.25, no.1: 113-143.

The World Bank. 2012. Annual Report 2012. Washington: The World Bank.

Thioune, R.M.C. 2003. Information and communication technologies for development in Africa: Opportunities and challenges for community development. Volume 1. Ottawa: IDRC. Available: http://www.idrc.ca 
Venkatesh, V., Morris, M.G., Davis, G.B., and Davis, F.D. (2003). User acceptance of information technology: Toward a unified view. MIS Quarterly, Vol.27, no.3: 425-478. Available at: https://www.jstor.org/stable/pdf/30036540.pdf

Yamane, T. 1967. Statistics: An introductory analysis, 2nd Ed., New York: Harper and Row.

Yang, H.-L., and Cheng, H.-H. 2009. Creative self-efficacy and its factors: An empirical study of information system analysts and programmers. Computers in Human Behavior, Vol. 25 no.2: 429-438. Available at: https://doi.org/10.1016/j.chb.2008.10.005

Yusliza, M. Y., Zikri, M., Mohd Salehuddin, M. Z., Emry, S. P., and Emmaliana, R. 2009. Individual differences, Perceived ease of use and perceived usefulness in ICT usage. Journal of Computer and Infomation Science, Vol.2, no.1: 76-83.

Zaremohzzabieh Z., Samah, B. A., Muhammad, M., Omar, S. Z., Bolong, J., Hassan, M. S., Shaffril, H. A. M. 2015. A Test of the Technology Acceptance Model for Understanding the ICT Adoption Behavior of Rural Young Entrepreneurs, International Journal of Business and Management, Vol 10, No 2: $158 . \quad$ DOI: http://dx.doi.org/10.5539/ijbm.v10n2p158. 


\section{Appendix 1: The Survey Instrument}

\section{SECTION A}

\section{DEMOGRAPHIC PROFILE}

Please mark $(\sqrt{ })$ in the space provided adjacent / fill suitable information

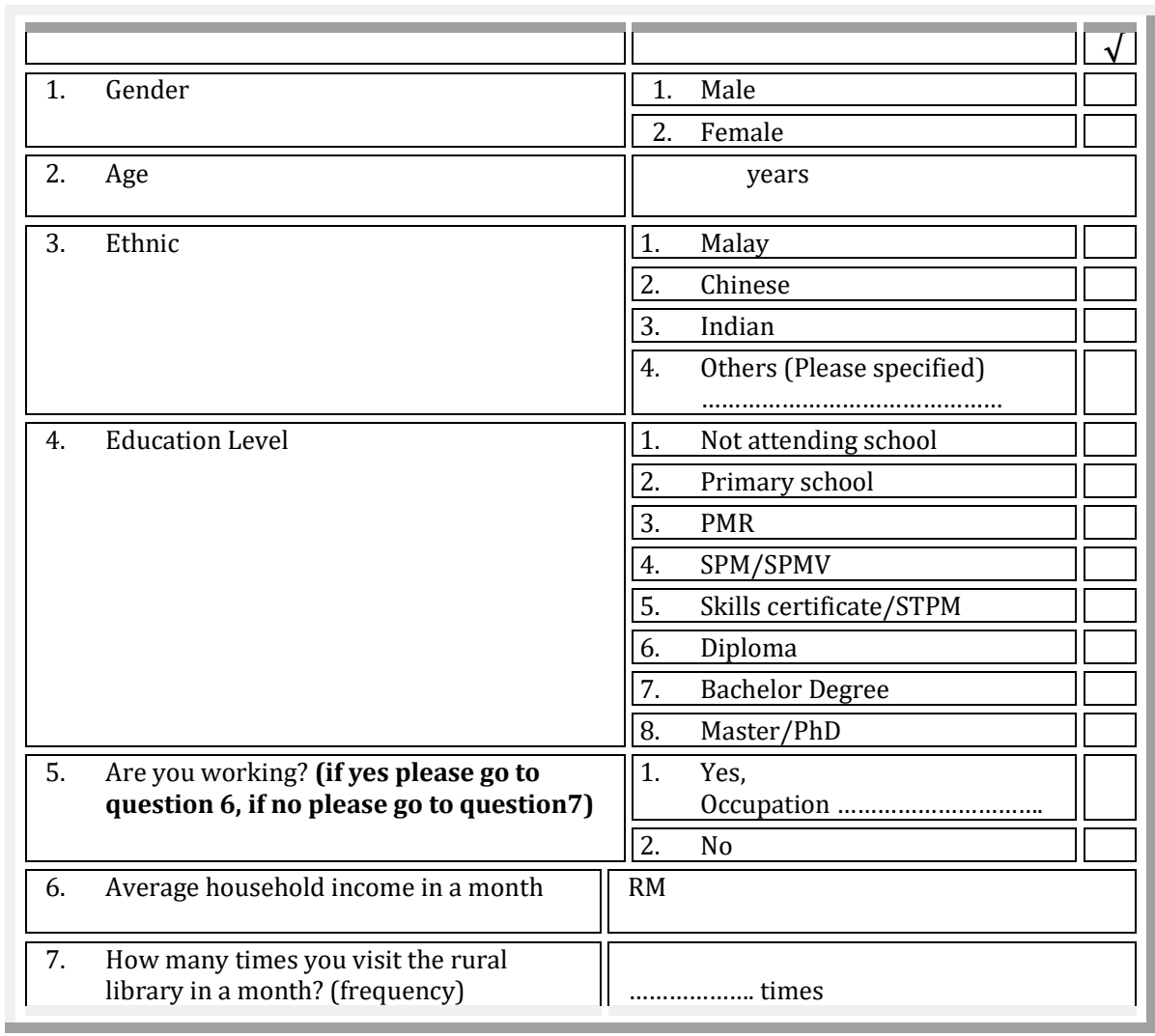

\section{SECTION B: USAGE OF ICT FACILITIES IN RURAL LIBRARY}

\begin{tabular}{|c|c|c|c|c|c|}
\hline \multirow{2}{*}{$\begin{array}{l}\text { INSTRUCTIONS } \\
\text { Please read all the following statements } \\
\text { and circle the numbers that most } \\
\text { suitables according to the scales given } \\
\text { scale } 1 \text { (Never ) to } 5 \text { (Very frequent) }\end{array}$} & (1) & (2) & (3) & (4) & (5) \\
\hline & Never & Seldom & Sometimes & Often & $\begin{array}{c}\text { Very } \\
\text { frequent }\end{array}$ \\
\hline
\end{tabular}

Gratification of ICT usage in rural library

(Leisure, filling time, entertainment, cognitive (information / news gaining, education/ work related, communication)

\begin{tabular}{|c|c|c|c|c|c|c|}
\hline \multicolumn{7}{|c|}{ I used ICT facilities provided by the rural library for: } \\
\hline 1 & Internet surfing (reading blog/portal) & 1 & 2 & 3 & 4 & 5 \\
\hline 2 & Downloading Image/ video & 1 & 2 & 3 & 4 & 5 \\
\hline 3 & Downloading songs & 1 & 2 & 3 & 4 & 5 \\
\hline 4 & $\begin{array}{l}\text { Downloading related documents (cth: receipe, journal, article, } \\
\text { etc.) }\end{array}$ & 1 & 2 & 3 & 4 & 5 \\
\hline 5 & Eliminate boredom & 1 & 2 & 3 & 4 & 5 \\
\hline 6 & Fill the free time & 1 & 2 & 3 & 4 & 5 \\
\hline 7 & $\begin{array}{l}\text { Online reading (novel/ books/article/ magazine/ comic/ } \\
\text { anime) }\end{array}$ & 1 & 2 & 3 & 4 & 5 \\
\hline 8 & Sending image/video & 1 & 2 & 3 & 4 & 5 \\
\hline 9 & Received image/video & 1 & 2 & 3 & 4 & 5 \\
\hline 10 & Listening to music & 1 & 2 & 3 & 4 & 5 \\
\hline 11 & Watching video & 1 & 2 & 3 & 4 & 5 \\
\hline 12 & Playing games(offline/ online game) & 1 & 2 & 3 & 4 & 5 \\
\hline 13 & Reading online newspaper & 1 & 2 & 3 & 4 & 5 \\
\hline 14 & $\begin{array}{l}\text { Getting news/ latest information on current issues (politic, } \\
\text { crimes, sports, health and others) }\end{array}$ & 1 & 2 & 3 & 4 & 5 \\
\hline
\end{tabular}




\begin{tabular}{|c|l|l|l|l|c|c|}
\hline 15 & Getting information on association activities & 1 & 2 & 3 & 4 & 5 \\
\hline 16 & $\begin{array}{l}\text { Getting information about courses from association/ } \\
\text { ministry/ university }\end{array}$ & 1 & 2 & 3 & 4 & 5 \\
\hline 17 & Getting information about businesses/ entrepreneurship & 1 & 2 & 3 & 4 & 5 \\
\hline 18 & $\begin{array}{l}\text { Getting information related on education/ completing } \\
\text { assignment/ completing tasks }\end{array}$ & 1 & 2 & 3 & 4 & 5 \\
\hline 19 & Completing school assignment/ completing tasks & 1 & 2 & 3 & 4 & 5 \\
\hline 20 & Online learning (academic/ self-knowledge) & 1 & 2 & 3 & 4 & 5 \\
\hline 21 & Getting information on job vacancies & 1 & 2 & 3 & 4 & 5 \\
\hline 22 & $\begin{array}{l}\text { Getting information about courses to improve the quality of } \\
\text { work }\end{array}$ & 1 & 2 & 3 & 4 & 5 \\
\hline 23 & Working online & 1 & 2 & 3 & 4 & 5 \\
\hline 24 & $\begin{array}{l}\text { Doing e-government businesses (e-filing, e-tax, e-license, to } \\
\text { check for results) }\end{array}$ & 1 & 2 & 3 & 4 & 5 \\
\hline 25 & Doing banking transactions through e-banking facilities & 1 & 2 & 3 & 4 & 5 \\
\hline 26 & Doing online trade and sells & 1 & 2 & 3 & 4 & 5 \\
\hline 27 & Reading email from teacher/ lecturer/ employer/ employee & 1 & 2 & 3 & 4 & 5 \\
\hline 28 & Sending email from teacher/ lecturer/ employer/ employee & 1 & 2 & 3 & 4 & 5 \\
\hline 29 & Communicate with friends through social media and email & 1 & 2 & 3 & 4 & 5 \\
\hline 30 & Communicate with families through social media and email & 1 & 2 & 3 & 4 & 5 \\
\hline 31 & Others. Please specified .................................................. & 1 & 2 & 3 & 4 & 5 \\
\hline
\end{tabular}

\section{SECTION C: ICT FACILITIES FACTOR}

\begin{tabular}{|c|c|c|c|c|c|c|c|c|}
\hline \multirow{2}{*}{\multicolumn{2}{|c|}{$\begin{array}{l}\text { INSTRUCTIONS } \\
\text { Please read each item below and give } \\
\text { your answer by circling the } \\
\text { appropriate number on a scale from } 1 \\
\text { (Strongly disagree) to } 5 \text { (Strongly } \\
\text { agree) }\end{array}$}} & (1) & (2) & (3) & & (4) & & (5) \\
\hline & & $\begin{array}{l}\text { Strongly } \\
\text { disagree }\end{array}$ & Disagree & $\begin{array}{l}\text { Neitl } \\
\text { agree } \\
\text { disag }\end{array}$ & & Agree & & $\begin{array}{l}\text { ongly } \\
\text { gree }\end{array}$ \\
\hline \multicolumn{9}{|c|}{ How well do you assess overall the following ICT facilities factors: } \\
\hline \multicolumn{9}{|c|}{ INFORMATION COMMUNICATION TECHNOLOGY (ICT) } \\
\hline 1 & \multicolumn{3}{|c|}{ Numbers of computer provided were sufficient } & 1 & 2 & 3 & 4 & 5 \\
\hline 2 & \multicolumn{3}{|c|}{ Computer provided free from any difficulties } & 1 & 2 & 3 & 4 & 5 \\
\hline 3 & \multicolumn{3}{|c|}{ Computer provided always maintained and repaired } & 1 & 2 & 3 & 4 & 5 \\
\hline 4 & \multicolumn{3}{|c|}{ Provided computers equipped with Internet } & 1 & 2 & 3 & 4 & 5 \\
\hline 5 & \multicolumn{3}{|l|}{ Provided computers are up to date } & 1 & 2 & 3 & 4 & 5 \\
\hline 6 & \multicolumn{3}{|l|}{ Computer facilities are satisfactory } & 1 & 2 & 3 & 4 & 5 \\
\hline 7 & \multicolumn{3}{|l|}{ Internet facilities are satisfactory } & 1 & 2 & 3 & 4 & 5 \\
\hline 8 & \multicolumn{3}{|c|}{ Internet speed in rural library were satisfactory } & 1 & 2 & 3 & 4 & 5 \\
\hline 9 & \multicolumn{3}{|c|}{$\begin{array}{l}\text { The time allocated for the computer use in the library are } \\
\text { inadequate }\end{array}$} & 1 & 2 & 3 & 4 & 5 \\
\hline 10 & \multicolumn{3}{|c|}{$\begin{array}{l}\text { The time allocated for the Internet use in the library are } \\
\text { inadequate }\end{array}$} & 1 & 2 & 3 & 4 & 5 \\
\hline 11 & \multicolumn{3}{|c|}{$\begin{array}{l}\text { I was allowed to use the facilities ICT provided by the library } \\
\text { without barriers }\end{array}$} & 1 & 2 & 3 & 4 & 5 \\
\hline 12 & \multicolumn{3}{|c|}{$\begin{array}{l}\text { People (residents and foreigners) are allowed to use ICT } \\
\text { facilities in the rural library }\end{array}$} & 1 & 2 & 3 & 4 & 5 \\
\hline 13 & \multicolumn{3}{|c|}{ 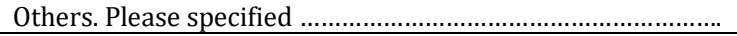 } & 1 & 2 & 3 & 4 & 5 \\
\hline
\end{tabular}

SECTION D: BEHAVIOR FACTOR

The following questions are related to behavioral factors including attitudes, perceived ease of use, perceived usefulness, subjective norms, perceived behavioral control and self-efficacy when using ICT in Rural Library. INSTRUCTIONS

Please read each item below and give your answer by circling the appropriate number on a scale from 1 (Strongly disagree ) to 5 (Strongly agree)

\begin{tabular}{|c|c|c|c|c|}
\hline $\begin{array}{c}\text { Strongly } \\
\text { disagree } \\
\text { (1) }\end{array}$ & Disagree & $\begin{array}{c}\text { Neither } \\
\text { agree or } \\
\text { disagree } \\
\text { (3) }\end{array}$ & Agree & $\begin{array}{c}\text { Strongly } \\
\text { agree } \\
\text { (5) }\end{array}$ \\
\hline
\end{tabular}

\begin{tabular}{|c|c|c|c|c|c|}
\hline \multicolumn{6}{|l|}{ ATTITUDE } \\
\hline $\begin{array}{l}\text { 1. I feel comfortable using ICT (computer/internet/ smartphone etc.) } \\
\text { because it is user friendly }\end{array}$ & 1 & 2 & 3 & 4 & 5 \\
\hline 2. Using ICT gives me confidence in managing daily life & 1 & 2 & 3 & 4 & 5 \\
\hline 3. I feel left out if not using the ICT & 1 & 2 & 3 & 4 & 5 \\
\hline 4. I enjoy using ICT for daily tasks & 1 & 2 & 3 & 4 & 5 \\
\hline 5. I prefer to use ICT than other equipment & 1 & 2 & 3 & 4 & 5 \\
\hline 6. I encourage other villagers and my family to use ICT & 1 & 2 & 3 & 4 & 5 \\
\hline 7. I like to promote the use of ICT to others & 1 & 2 & 3 & 4 & 5 \\
\hline 8. I like to teach others on how to use ICT & 1 & 2 & 3 & 4 & 5 \\
\hline 9. I feel like I become more productive when using ICT & 1 & 2 & 3 & 4 & 5 \\
\hline $\begin{array}{l}\text { 10. I do not care on ICT training and courses in enhancing my } \\
\text { knowledge and ICT skills }\end{array}$ & 1 & 2 & 3 & 4 & 5 \\
\hline
\end{tabular}




\begin{tabular}{|c|c|c|c|c|c|}
\hline \multicolumn{6}{|l|}{ PERCEIVED USEFULNESS } \\
\hline \multicolumn{6}{|l|}{ While using ICT in rural library I could ... } \\
\hline 1. Increase my knowledge & 1 & 2 & 3 & 4 & 5 \\
\hline 2. Share my knowledge & 1 & 2 & 3 & 4 & 5 \\
\hline 3. Improve my skills related to education/ job & 1 & 2 & 3 & 4 & 5 \\
\hline 4. Simplify my daily routines & 1 & 2 & 3 & 4 & 5 \\
\hline 5. Save my money/ cost & 1 & 2 & 3 & 4 & 5 \\
\hline 6. $\quad$ Save space & 1 & 2 & 3 & 4 & 5 \\
\hline 7. Save times & 1 & 2 & 3 & 4 & 5 \\
\hline 8. Improve work/ study quality & 1 & 2 & 3 & 4 & 5 \\
\hline 9. Doubling the quantity of work/ study & 1 & 2 & 3 & 4 & 5 \\
\hline 10. Delaying the process of two-way communication & 1 & 2 & 3 & 4 & 5 \\
\hline
\end{tabular}

\begin{tabular}{|c|c|c|c|c|c|}
\hline \multicolumn{6}{|l|}{ PERCEIVED EASE OF USE } \\
\hline \multicolumn{6}{|l|}{ In rural library ... } \\
\hline ICT services and facilities provided are easy to use & 1 & 2 & 3 & 4 & 5 \\
\hline Sending emails is easy & 1 & 2 & 3 & 4 & 5 \\
\hline $\begin{array}{l}\text { 3. Using social media is easy (Facebook, Tweeter, Instagram, } \\
\text { WhatsApp) }\end{array}$ & 1 & 2 & 3 & 4 & 5 \\
\hline $\begin{array}{l}\text { 4. Uploading and downloading files is easy (songs, videos, } \\
\text { documents) }\end{array}$ & 1 & 2 & 3 & 4 & 5 \\
\hline 5. Using Internet search engines is easy (Google, Yahoo) & 1 & 2 & 3 & 4 & 5 \\
\hline $\begin{array}{l}\text { 6. Using e-government services (eg.: e-tax, e-license, checking } \\
\text { examination results) is easy }\end{array}$ & 1 & 2 & 3 & 4 & 5 \\
\hline Using online banking through internet is easy & 1 & 2 & 3 & 4 & 5 \\
\hline Reading online newspaper/magazine/ novel/ journal is easy & 1 & 2 & 3 & 4 & 5 \\
\hline 9. Listening music/ watching video through Internet is easy & 1 & 2 & 3 & 4 & 5 \\
\hline $\begin{array}{l}\text { 10. Getting news/ latest information on current issues (politic, crime, } \\
\text { sports, health and others) is not easy }\end{array}$ & 1 & 2 & 3 & 4 & 5 \\
\hline
\end{tabular}

\begin{tabular}{|c|c|c|c|c|c|}
\hline \multicolumn{6}{|l|}{ SUBJECTIVE NORM } \\
\hline $\begin{array}{l}\text { 1. Related agencies promotes and encourages the use of ICT the } \\
\text { villagers }\end{array}$ & 1 & 2 & 3 & 4 & 5 \\
\hline $\begin{array}{l}\text { 2. Related agencies provide financial assistance to the rural library } \\
\text { to handle activities with ICT usage }\end{array}$ & 1 & 2 & 3 & 4 & 5 \\
\hline $\begin{array}{l}\text { 3. Related agencies encouraged me to use ICT in completing daily } \\
\text { tasks and current activities. }\end{array}$ & 1 & 2 & 3 & 4 & 5 \\
\hline $\begin{array}{l}\text { 4. The quality of ICT services and facilities available at rural library } \\
\text { in my village is good }\end{array}$ & 1 & 2 & 3 & 4 & 5 \\
\hline $\begin{array}{l}\text { 5. Majority of the villagers encouraged me to use ICT in rural } \\
\text { library }\end{array}$ & 1 & 2 & 3 & 4 & 5 \\
\hline 6. My family members encouraged me to use ICT in rural library & 1 & 2 & 3 & 4 & 5 \\
\hline 7. My friends encouraged me to use ICT in rural library & 1 & 2 & 3 & 4 & 5 \\
\hline 8. My JKKK committee encouraged me to use ICT in rural library & 1 & 2 & 3 & 4 & 5 \\
\hline 9. My surroundings encouraged me to use ICT in rural library & 1 & 2 & 3 & 4 & 5 \\
\hline \multicolumn{6}{|l|}{ PERCEIVED BEHAVIOR CONTROL } \\
\hline \multicolumn{6}{|l|}{ I didn't use ICT in rural library because of ... } \\
\hline 1. Do not have the skills to use ICT/ do not know how to use & 1 & 2 & 3 & 4 & 5 \\
\hline 2. Not interested in using ICT & 1 & 2 & 3 & 4 & 5 \\
\hline 3. Does not requiring the ICT usage & 1 & 2 & 3 & 4 & 5 \\
\hline 4. Cannot afford (the cost of use/ transportation) & 1 & 2 & 3 & 4 & 5 \\
\hline 5. I am not proficient in English language & 1 & 2 & 3 & 4 & 5 \\
\hline 6. Do not have time/ busy & 1 & 2 & 3 & 4 & 5 \\
\hline 7. Insufficient computer facilities provided & 1 & 2 & 3 & 4 & 5 \\
\hline $\begin{array}{l}\text { 8. Lack of information on signage to ICT facilities and what other } \\
\text { services provided }\end{array}$ & 1 & 2 & 3 & 4 & 5 \\
\hline 9. Facilities and equipment provided were outdated & 1 & 2 & 3 & 4 & 5 \\
\hline $\begin{array}{l}\text { 10. Facilities and equipment provided were always damaged and } \\
\text { were not repaired }\end{array}$ & 1 & 2 & 3 & 4 & 5 \\
\hline 11. Internet speed were unsatisfactory & 1 & 2 & 3 & 4 & 5 \\
\hline $\begin{array}{l}\text { 12. Most preferred other Internet services (eg.: TM, Celcom, Digi, } \\
\text { Maxis, U Mobile) }\end{array}$ & 1 & 2 & 3 & 4 & 5 \\
\hline 13. Prefer to other ICT center & 1 & 2 & 3 & 4 & 5 \\
\hline 14. The limited time in using ICT & 1 & 2 & 3 & 4 & 5 \\
\hline 15. There are several websites been blocked & 1 & 2 & 3 & 4 & 5 \\
\hline 16. No privacy & 1 & 2 & 3 & 4 & 5 \\
\hline 17. The rural library closed when needed & 1 & 2 & 3 & 4 & 5 \\
\hline 18. My surroundings did not encourage me to use ICT & 1 & 2 & 3 & 4 & 5 \\
\hline
\end{tabular}

\section{SELF EFFICACY}

1. Overall, I believe I can use ICT very well

\begin{tabular}{|l|l|l|l|l|}
1 & 2 & 3 & 4 & 5 \\
\hline
\end{tabular}




\begin{tabular}{|ll|l|l|l|l|l|}
\hline 2. & I believe I can use ICT application in harder level & 1 & 2 & 3 & 4 & 5 \\
\hline 3. & I believe I can mastering knowledge and ICT skills & 1 & 2 & 3 & 4 & 5 \\
\hline 4. & I am confident will continue to use ICT & 1 & 2 & 3 & 4 & 5 \\
\hline $\begin{array}{l}\text { 5. I am sure I will solve all the problems associated with the use of } \\
\text { ICT }\end{array}$ & 1 & 2 & 3 & 4 & 5 \\
\hline
\end{tabular}

\section{SECTION E: BENEFITS OBTAINED BY INTERNET USAGE IN RURAL LIBRARY TOWARDS POSITIVE RURAL YOUTH DEVELOMENT}

The section was formed based on the framework of Positive Youth Development (Lerner et al., 2005), as a measure of the benefits to be gained when using ICT facilities in the rural library

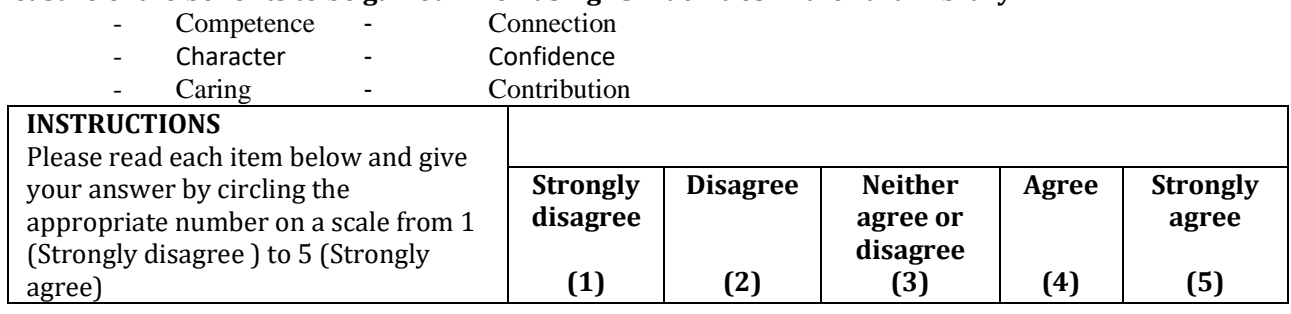

\begin{tabular}{|c|c|c|c|c|c|}
\hline \multicolumn{6}{|l|}{ COMPETENCE } \\
\hline \multicolumn{6}{|c|}{ Using ICT in the rural library, ....................... } \\
\hline 1. My competency level in creative thinking can be increased & 1 & 2 & 3 & 4 & 5 \\
\hline 2. My competency level in academic improve & 1 & 2 & 3 & 4 & 5 \\
\hline 3. My competency level in social life improve & 1 & 2 & 3 & 4 & 5 \\
\hline 4. My information searching technique improve more effectively & 1 & 2 & 3 & 4 & 5 \\
\hline 5. My critical thinking skills can be improved in healthier way & 1 & 2 & 3 & 4 & 5 \\
\hline
\end{tabular}

\begin{tabular}{|c|c|c|c|c|c|}
\hline \multicolumn{6}{|l|}{ CONNECTION } \\
\hline \multicolumn{6}{|l|}{ Using ICT in the rural library, ...................... } \\
\hline 1. My relations with my families are better and friendlier & 1 & 2 & 3 & 4 & 5 \\
\hline 2. My relations with my close and distant relatives are better & 1 & 2 & 3 & 4 & 5 \\
\hline $\begin{array}{l}\text { 3. My relations with my colleagues are better (school, universities, } \\
\text { workplace) }\end{array}$ & 1 & 2 & 3 & 4 & 5 \\
\hline 4. My relations with teachers/ lecturers/ employer are better & 1 & 2 & 3 & 4 & 5 \\
\hline 5. My relations with neighbours and villagers & 1 & 2 & 3 & 4 & 5 \\
\hline
\end{tabular}

\begin{tabular}{|c|c|c|c|c|c|c|}
\hline \multicolumn{7}{|c|}{ CHARACTER } \\
\hline \multicolumn{7}{|c|}{ Using ICT in the rural library, ..................... } \\
\hline 1. & Has taught me to be a person with integrity & 1 & 2 & 3 & 4 & 5 \\
\hline & Developed me to be responsible & 1 & 2 & 3 & 4 & 5 \\
\hline & Developed me to be moralized & 1 & 2 & 3 & 4 & 5 \\
\hline & Developed me to be more respectful toothers & 1 & 2 & 3 & 4 & 5 \\
\hline & Raised my awareness on ethics of Internet usage & 1 & 2 & 3 & 4 & 5 \\
\hline
\end{tabular}

\begin{tabular}{|c|c|c|c|c|c|c|}
\hline \multicolumn{7}{|c|}{ CONFIDENCE } \\
\hline \multicolumn{7}{|c|}{ 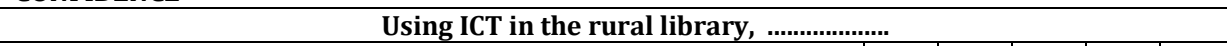 } \\
\hline 1 & Give me high level of confidence in gaining knowledge & 1 & 2 & 3 & 4 & 5 \\
\hline 2. & Game me the confidence to communicate with the community & 1 & 2 & 3 & 4 & 5 \\
\hline & Allow me to be more independent & 1 & 2 & 3 & 4 & 5 \\
\hline & Taught me to respect the dignity & 1 & 2 & 3 & 4 & 5 \\
\hline & Give me confidence to use ICT & 1 & 2 & 3 & 4 & 5 \\
\hline
\end{tabular}

\begin{tabular}{|c|c|c|c|c|c|c|}
\hline \multicolumn{7}{|c|}{ CARING } \\
\hline \multicolumn{7}{|c|}{ Using ICT in the rural library, ..................... } \\
\hline 1. & Make me a person with high human values & 1 & 2 & 3 & 4 & 5 \\
\hline & Make me a person with empathy / understanding & 1 & 2 & 3 & 4 & 5 \\
\hline & Allow me to share feelings with others & 1 & 2 & 3 & 4 & 5 \\
\hline & Made me understand the meaning of justice and hardship & 1 & 2 & 3 & 4 & 5 \\
\hline & Encourage me to help others who need help & 1 & 2 & 3 & 4 & 5 \\
\hline
\end{tabular}

\begin{tabular}{|cl|c|c|c|c|c|}
\hline \multicolumn{9}{|c|}{ Using ICT in the rural library, .................. } \\
\hline \multicolumn{7}{|l|}{ CONTRIBUTION } \\
\hline 1. & Giving me the opportunity to share knowledge with community & 1 & 2 & 3 & 4 & 5 \\
\hline 2. & Give me the opportunity to provide views and opinions & 1 & 2 & 3 & 4 & 5 \\
\hline 3. & Allow me to get involved in local community programs & 1 & 2 & 3 & 4 & 5 \\
\hline 4. & Allow me to contribute energy and money to the community & 1 & 2 & 3 & 4 & 5 \\
\hline 5. & $\begin{array}{l}\text { Involve me in the planning/ implimentation of program activities } \\
\text { for the local community }\end{array}$ & 1 & 2 & 3 & 4 & 5 \\
\hline
\end{tabular}


Samsuddin, S.F., Omar, S.Z. \& Shaffril, H.A.M.

Appendix 2: Discriminant Validity of the Latent Constructs

\begin{tabular}{|c|c|c|c|c|c|c|c|c|c|c|c|c|c|c|c|}
\hline Constructs & AVE & 1 & 2 & 3 & 4 & 5 & 6 & 7 & 8 & 9 & 10 & 11 & 12 & 13 & 14 \\
\hline Competence & 0.604 & 0.777 & & & & & & & & & & & & & \\
\hline Connection & 0.623 & 0.699 & 0.789 & & & & & & & & & & & & \\
\hline Character & 0.658 & 0.741 & 0.716 & 0.811 & & & & & & & & & & & \\
\hline Confidence & 0.663 & 0.717 & 0.691 & 0.814 & 0.838 & & & & & & & & & & \\
\hline Caring & 0.646 & 0.653 & 0.573 & 0.719 & 0.735 & 0.804 & & & & & & & & & \\
\hline Contribution & 0.626 & 0.718 & 0.634 & 0.739 & 0.723 & 0.770 & 0.791 & & & & & & & & \\
\hline ICT & 0.547 & 0.225 & 0.254 & 0.309 & 0.254 & 0.282 & 0.259 & 0.740 & & & & & & & \\
\hline AT & 0.522 & 0.610 & 0.464 & 0.544 & 0.488 & 0.426 & 0.514 & 0.380 & 0.722 & & & & & & \\
\hline PU & 0.697 & 0.581 & 0.529 & 0.637 & 0.540 & 0.389 & 0.552 & 0.313 & 0.662 & 0.835 & & & & & \\
\hline PEOU & 0.528 & 0.557 & 0.524 & 0.615 & 0.531 & 0.488 & 0.487 & 0.451 & 0.650 & 0.642 & 0.727 & & & & \\
\hline SN & 0.556 & 0.561 & 0.531 & 0.539 & 0.507 & 0.480 & 0.542 & 0.524 & 0.518 & 0.476 & 0.642 & 0.746 & & & \\
\hline PBC & 0.575 & -0.289 & -0.122 & -0.194 & -0.180 & -0.125 & -0.159 & 0.054 & -0.255 & -0.300 & -0.159 & -0.163 & 0.758 & & \\
\hline SE & 0.511 & 0.715 & 0.487 & 0.667 & 0.601 & 0.552 & 0.561 & 0.276 & 0.622 & 0.631 & 0.607 & 0.488 & -0.351 & 0.831 & \\
\hline GIU & 0.529 & 0.264 & 0.182 & 0.151 & 0.124 & 0.201 & 0.240 & 0.105 & 0.296 & 0.132 & 0.204 & 0.272 & 0.023 & 0.171 & 0.727 \\
\hline
\end{tabular}

The squared root of AVE of each construct (on the Diagonal) and Correlation Coefficient (on the OffDiagonal)

Note. ICT $=I C T$ Factor, AT= Attitude, PU= Perceived usefulness, PEOU= Perceived ease of use, $\mathrm{SN}=$ Subjective norm, $\mathrm{PBC}=$ Perceived behaviour control, $\mathrm{SE}=$ Self efficacy, GIU=Gratification ICT Usage 